1812 , the re-appearance of which is shortly expected. We have already mentioned that sweeping-ephemerides have been prepared by Herr Mahn, of Strasburg, and may be found in "Vierteljahrsschrift der Astronomischen Gesellschaft, 12 Jahrgang, 2 Heft."

\section{MR. DARWIN AT CAMBRIDGE}

$A^{s}$ we intimated last week, the honorary degree of LL,D. was conferred on Mr. Charles Darwin at Cambridge on Saturday. The occasion was in many ways remarkable, and suggestive of reflections that must occur to all, and which need not be put formally into words. The university seems to have been conscious of the honour Mr. Darwin was doing it, and seldom, it is said, was a more exciting scene seen in the senate-house. To appoint a special congregation of the senate for the transaction of no other business but the conferment of a solitary degree, although it be honoris cansa, is only resorted to in exceptional and important cases. The step taken by the university evidently has met with general approval to judge by the tone of the assembly in the senate-house on Saturday. The building was packed, and the inevitable pastime of the undergraduates assumed a form extremely appropriate, however questionable its taste may have been.

The appearance of Mr. Darwin entering the senatehouse by a side door, with the Master of Christ's, of which College Mr. Darwin is a member, was the signal for a burst of applause which was evidently the result of genuine enthusiasm, and was certainly thoroughly hearty. At two o'clock the Vice-Chancellor took his seat on the raised cais, and the business of the day began. Standing side by side with Mr. Darwin in the centre of the senatehouse, Mr. Sandys, the Public Orator, commenced the delivery of the customary Latin oration. Interruptions from the galleries occasionally interfered with the orator's efforts to make himself heard, but the pleasant manner of his delivery, combined with great tact and judgment, helped to quiet the undergraduates" "chaff," and assisted him materially in getting through his task.

We have been favoured with a copy of the Public Orator's address, which our readers will no doubt read with interest, both on account of the elegance of its Latin, and for its neat summary of Dr. Darwin's work; indeed, in its way, it is somewhat of a literary curiosity.

" ORA'TIO AB ORATORE PUBLICO HABITA CANTABRIGIAE DIE XVII NOVEMBRIS A. S. MDCCCLXXVII

"Dignissime domine, domine Procancellarie, êt tota Academia :-

"Meministis Horatianum illud, 'fortes creantur fortibus'; vix igitur necesse est commemorare viri huius de rerum natura optime meriti patrem fuisse medicum egregium, avum poetam quoque insignem. 'Doctrina sed vim promovet insitam '; iuvat igitur recordari pueritiam huius fovisse scholam celeberrimam Salopiensem; adulescentiam aluisse non modo Caledonicas illas Athenas, sed in hac etiam Academia Miltoni nostri Collegium. Tanti in laudem alumni, nisi fallor, ipsa paterni fluminis nympha, non immemor hunc primum patefecisse insularum corallinarum originem, illa inquam Sabrina quae Miltoni in carmine vivit,

curalio nitida roseum caput exseret unda,

frontemque tam venerabilem sua praecinget corolla.

"Quanta cum voluptate accepimus insularum illarum circulos, sese e vadis sensim attollentes, quasi florum immortalium palmarumque victricium corona locos illos virides placidosque in Oceani campo desigrare, ubi priores insulae depressae et sepultae sunt: Quam facete describit, quo modo varios sensuum affectus expriman indices illi vultus et ipsa tacitorum oculorum eloquentia; quo more apes, dum dulce illud nectar e flore delibant, quod continuandae floris stirpi utile sit, ipsae aliunde referant. Quam venuste explicat, quo modo captet Venus ipsa muscas; quali ex origine sint Veneris volucres, 'raucae, tua cura, palumbes'; quibus cantuum illecebris, quo splendore plumarum, concilientur volucrum amores. Quam familiariter, velut rex ille excellenti sapientia, de tot rebus disserit, quicquid volấ, quicquid natat, quicquid serpit humi; quam varia eruditione disputat de fabuloso illo lepadum balanorumque marinorum genere, de montium igneorum miraculis, sed idem de gracili vitis pampino et lentis hederarum bracchiis in apricum enitentium; quanta liberalitate in patrocinium suum vindicat non modo 'aurea pavonum saecla,' sed etiam minus pulchram simiarum familiam. Qua de re quanquam poeta vetus dixit, 'simia quam similis nobis'; nobis tamen, viri Academici, cum oratore Romano, viro Academicae praesertim philosophiae dedito, gloriari licet, ' mores' esse 'in utroque dispares.'

"Illud certe extra omnem controversiam constat, pulchrum esse tantam rerum naturae varietaten contemplari, regiones remotas invisere, silvarum incaeduarum solitudinem penetrare, insularum prope ignotarum recessus perscrutari, varias denique animalium formas comparare inter se et distinguere ; pulchrius, haec omnia accuratissime observata aliorum in usum voluptatemque litterarum mandare monumentis; omnium pulcherrimum, infinita talium rerum multitudine ad leges quam paucissimas revocata, ipsum fontem et originem omnium repetere. Quanta igitur laude vir hic dignus est, qui adhuc iuvenis, aliorum magis quam suo commodo, tot terras lustraverit, lustratas feliciter descripserit; qui maturiore aetate, tot generibus animantium et earum rerum quas terra gignit diligenter investigatis, illi praesertim legi constituendae operam dederit, qua docere conatus est, ita e perpetuo prope ad internecionem debellantium certamine aptissimam quamque novae stirpi propagandae speciem vivam victricemque superesse, ut tot species inter se diversae alia ex alia minutatim per immensam annorum serien. generari potuerint.

$$
\begin{aligned}
& \text { 'Usus et impigrae simui experientia mentis } \\
& \text { paulatim docuit pedetentim progredientes. } \\
& \text { sic unumquicquid paulatim protrahit aetas } \\
& \text { in medium ratioque in luminis erigit oras. } \\
& \text { namque alid ex alio clarescere et ordine debet } \\
& \text { omnibus, ad summum donec venere cacumen.' }
\end{aligned}
$$

"Tu vero, qui leges naturae tam docte illustraveris, legum doctor nobis esto.

"Duco ad yos Carolum DaRwin."

The conclusion of this oration was greeted with lout applause, and the proceedings ended with the ViceChancellor conferring the degree on Mr. Darwin in the usual formal manner.

In the evening the anniversary dinner of the Cambridge Philosophical Society was given in the Hall of Clare College. The president of the Society, Prof. Liveing, occupied the chair, and among the visitors present were Professors Huxley, Ramsay, Tyndall, Parker, Burdon Sanderson, Drs. Günther, Wilks, Pye Smith, Mr. Francis Galton, \&c. Prof. Ramsay proposed the toast of the University of Cambridge, and Prof. Huxley responded to that of Mr. Darwin, who was unable to be present. In his speech Prof. Huxley sarcastically spoke of the University as reserving its highest honoux till all other distinctions had been heaped on Mr. Darwin, that its own chaplet might crown the whole, and not be covered up. Prof. Huxley spoke of Mr. Darwin as the foremost among men of science, with one exception, since the days of Aristotle.

A special meeting of the Philosophical Society is to be held next Monday in the combination room of Christ's College, to consider the best means of making a permanent memorial of Mr. Darwin in the University. Would not a Darwin Professorship of General Biology be a very suitable memorial? 